\title{
Burden and factors associated with Generalized Anxiety Disorder symptoms among the Pakistani population during the Corona-virus disease 2019
}

Maryam Pyar Ali Lakhdir ( $\square$ maryam.ali@aku.edu )

Aga Khan University

Apsara Ali Nathwani

Aga Khan University

Ghazal Peerwani

Aga Khan University

Syed lqbal Azam

Aga Khan University

Romaina Iqbal

Aga Khan University

Nargis Asad

Aga Khan University

\section{Research Article}

Keywords: COVID 19, generalized anxiety disorder, Pakistan

Posted Date: June 8th, 2021

DOI: https://doi.org/10.21203/rs.3.rs-598605/v1

License: (1) This work is licensed under a Creative Commons Attribution 4.0 International License.

Read Full License 


\section{Abstract \\ Background}

Psychological impact of the COVID 19 pandemic has been expected and widely predicted, but its associated factors are not measured predominantly in low- and middle-income countries. This study aims to determine the burden and factors associated with generalized-anxiety-disorder in the Pakistani population amidst the COVID 19 pandemic

\section{Methods}

We conducted a web-based cross-sectional survey on 1679 Pakistani residents who had access to the study questionnaire broadcasted via the Google form. Generalized-anxiety-disorder was screened through a validated tool of the Generalized-Anxiety-Disorder 7 scale. Multiple Ordinal Regression was used to identify the factors associated generalized anxiety disorder and the results were reported as adjusted odds ratios with $95 \%$ confidence intervals.

\section{Results}

Most of the participants $(70.8 \% ; n=1189)$ were screened positive for generalized-anxiety-disorder, out of which moderate and severe symptoms were seen in $22 \%(n=365)$ and $18 \%(n=301)$ of them, respectively. The mean score for generalized-anxiety was $8.57(\mathrm{SD}= \pm 5.88)$. A significant interaction was seen between gender and perceived stress, indicating that females with high perceived stress had 30 times greater odds of generalized-anxiety as compared to females with low perceived stress $(95 \% \mathrm{Cl}$ : $20.02,44.46)$. Additionally, during the complete down, the odds of generalized-anxiety among respondents who frequently watched news were $1.72(95 \% \mathrm{Cl}: 1.06,2.77)$ times compared to participants who rarely watched the news. Furthermore, participant's current psychiatric illness, anxiousness about uncertainty, fear of getting infected from COVID, fear of loved one getting infected from COVID 19, worrying when the first case of COVID 19 was reported, indulgence in recreational activities, and current health status were found to be significantly associated with generalized-anxiety.

\section{Conclusion}

Study findings indicate an alarming increase in generalized anxiety adversely affecting the psychological well-being of respondents. Immediate interventions for offering psychological support need to be implemented to curtail the rapidly increasing morbidity due to anxiety related to the pandemic.

\section{Introduction}


The unprecedented COVID 19 pandemic initiated as an atypical pneumonia outbreak in Wuhan, China, in December 2019 soon became a global health threat. The exponential spread of the virus ensued in unparalleled social disruption, isolation and lockdowns affecting global economies, healthcare resources and individual routines(1). Millions of people around the world got infected, and hundreds of thousands of lives were lost during the first wave of the pandemic. The situation became more taxing for low, and middle-income countries (LMICs) as their already compromised financial and healthcare resources were not equipped enough to handle a crisis of such a massive scale(2). In addition to these challenges, a resource-limited country like Pakistan faced a unique challenge as it shares its boundaries with two of the most then pandemic affected countries, China and Iran. The pilgrims' return from Iran caused surging of the Corona cases resulting in fear and paranoia in the populace(3). The first fatal wave of pandemic faced by Pakistan infected 332,186 people, claimed 6795 lives and left 632 patients dependent on mechanical ventilation. These numbers have upsurge to 563,029 cases and 12,307 deaths in the second wave to date(4).

Prior outbreaks and epidemics are known to have a significant psychological impact on individuals (57). During 2002-2003 Severe Acute Respiratory Syndrome (SARS), higher levels of moderate to severe anxiety were in general population of Hong Kong(8). Similar situation was replicated during Middle East respiratory syndrome (MERS) in Korean population as high anger and anxiety levels were observed(9). Likewise substantial social, physical and psychological impact of COVID 19 is speculated across the world in both infected and non-infected individuals(10). In Pakistan, drastic steps were taken by the government in the form of enforcing a complete lockdown on 24th March 2020 to contain the virus, affecting multiple aspects of the life of more than 50 million people $(11,12)$. During this lockdown, more than half of the enterprises and small scale businesses were on the verge of closure, suicidal cases increased due to impoverishment, and daily wagers found it challenging to fulfil their basic necessities; hence complete lockdown was lifted and smart lockdowns were implemented $(12,13)$. These lockdowns caused social disruption as schools were closed, eateries and places of socialization were shut down; most people worked from home and were isolated. This was followed by hoarding of medical and basic amenities resulting in a shortage of essentials. Moreover, the unavailability of hospitals and medical staff also ensued after the peak in the pandemic was near. These multitude of factors might have caused fear, panic, hopeless, stress and anxiety in the mass populace $(14,15)$

Various studies across the globe have reported a higher burden of generalized anxiety disorder (GAD) in the general population during the pandemic $(16,17)$. GAD is defined as "excessive anxiety and worry, occurring more days than not for at least six months, about a number of events or activities". This anxiety is associated with distress, functional impairment, and physical symptoms, including muscle tension, sleep disturbance, restlessness, chronic headaches, and gastrointestinal symptoms (18). Internationally, in a nationwide study on 15,704 Germans, approximately $45 \%$ of the participants were found to have GAD symptoms(19). In the United Kingdom and Australia, almost $21 \%$ of the population was screened positive for GAD symptoms $(19,20)$. In the United States of America, similar findings were replicated as a substantial increase in GAD symptoms was seen during the pandemic compared to the pre-pandemic era (17.9\% vs 1.8\%)(1). Regionally, in Bangladesh, more than one-third of the population (38\%) reported 
higher anxiety levels, whereas almost $64 \%$ of Saudi residents had moderate to severe GAD $(17,21)$. In China, $32 \%$ of the population had GAD during the peak of the pandemic's first wave(16). Multiple factors are found to influence levels of anxiety during the pandemic, including gender, economic constraints, lack of COVID related knowledge, fear of uncertainty, fear of getting infected or losing a loved one to COVID, inadaptability, the impact of news and social media, lack of confidence in government and health care providers, quarantine, existing psychological illness, unpreparedness to handle crises, chronic comorbidities and paranoia of increasing cases and mortality(22). These factors were quite similar to the factors associated with mental disorders during SARS and MERS outbreaks including older age, females, participants with higher education, positive contact history, presence of infection like symptoms, inadequate resources and supplies, history of psychiatric illness, financial losses and increased use of social media(8, 9).

In Pakistan, multiple studies to determine generalized anxiety status during the pandemic in doctors (35\%) (23), university students (34\%) (24), adult women (42\%) (25) and healthcare professionals (85\%) (26) were conducted, but to the best of our knowledge, there isn't any nationwide study to determine the psychological impact of COVID 19 in the general population. Considering alarming moderate to severe levels of generalized anxiety in certain strata of society hints at a higher burden of anxiety in the general population. In a country like Pakistan with limited resources and unequipped mental health infrastructure, it is essential to determine and proactively tackle psychological morbidities before they culminate into a mental health crisis. Detrimental long term consequences of GAD, including suicidal tendencies, established mental illness, loss of productivity, substance abuse, and physical morbidities, also makes it a compulsion to cater to the psychological morbidities at the earliest(27). Moreover, the need for an evidence base to back up the second wave's preparedness measures also explains this study's rationale. The present study aims to estimate the prevalence of GAD in the general population amidst corona crises and also to determine factors associated with it.

\section{Methods}

A cross-sectional study was conducted on individuals belonging and currently residing in Pakistan, recruited via a web-based approach to determine the burden and factors associated with GAD amidst a pandemic. This study was approved by the Institutional Review Board (Aga Khan University Ethical Review Board). The questionnaire of this study in both English and Urdu languages was created on Google form, and a relevant link was generated to allow participants to access this form. The link of the questionnaire was advertised on social media platforms, including Facebook, Instagram, and Twitter, and sent to contacts via email, SMS, and WhatsApp. If the participant had internet access, received a link, and accessed the Google Form, an electronic consent was taken prior to the administration of the questionnaire. Individuals residing out of Pakistan were excluded from this study.

To screen GAD status in the respondents, the GAD-7 tool was used. This tool comprised of 7 questions with responses from 0 (not sure at all) to 3 (nearly every day) on a Likert scale. The range of this tool is 0-21. The definite cutoff of this tool to categorize GAD status was < 5 (no anxiety), 5-9 (mild anxiety), 
10-14 (moderate anxiety), and > 15 (severe anxiety). This tool has been validated on the general population amidst pandemic situations $(16,28)$. Further details about the tool are elaborated in the antecedent study.

A multitude of independent variables and their associations were assessed with GAD. Perceived stress was one of the covariate assessed via the Perceived stress scale-10 (PSS-10) tool. This tool comprised ten questions with responses from 0 (never) to 4 (very often) on a Likert scale. There were six positively constructed and four negatively constructed questions. The range of this tool is $0-40$. This tool has definite cut-offs to categorize stress levels 0-13 (low stress), 14-26 (moderate stress), and 27-40 (high stress)(29). This tool has been validated on the general population during the pandemic (30). The previous study highlights further details about this tool. Other covariates include sociodemographic characteristics, worriedness and fears related to COVID 19, perceptions of social media and government's role amidst pandemic, and knowledge about Coronavirus.

This study's required sample size was 1,535 at a $5 \%$ level of significance and $80 \%$ power. The assumption of this sample size was that the prevalence of moderate to severe anxiety levels in Pakistani population were expected to range between $8.1-53.8 \%$ with $2.5 \%$ absolute precision. Sample size based on assumptions of factors associated with GAD was also analyzed. Anticipated prevalence of different sociodemographic factors along with items related to worry, fear and knowledge related to corona virus among no mental health disorder ranging between 10.0-50.0\%, an anticipated prevalence ratio of 2 or more, ratio of no mental health disorder to mental health disorder ranging between 1 to 12 was assumed. 1,248 was the sample size with these assumptions at $80 \%$ power and $5 \%$ level of significance. The maximum sample size as per prevalence of GAD assumption was taken. As it was a web-based study, $10 \%$ of refusals and incomplete forms were anticipated. The final sample size was coming to be 1689 including $10 \%$ of refusals and incomplete forms. We managed to recruit 1679 participants in our study. A non-probability purposive sampling technique was adopted to conduct this survey.

Descriptive analysis of the outcome and independent variables was done. Mean \pm standard deviation was reported for quantitative variables, whereas frequency (percentage) was reported for categorical variables. Crude and adjusted odds ratios along with $95 \%$ confidence intervals were reported using simple and multiple ordinal regression respectively in order to determine factors influencing generalized anxiety disorder.

\section{Results}

\subsection{Characteristics of participants:}

The majority of the individuals participated in our online survey during the COVID 19 pandemic, were females $(72.7 \%)$, residents of Karachi (56.8\%), single (58.1\%), employed (40.8\%) and had graduate $(43.3 \%)$ and post graduate (40.6) level of education. The average age of the participants was 29.41 (SD = \pm 9.60 ) years and almost half of the sample were from the age cohort of 25-39 years. 


\subsection{Prevalence of Generalized Anxiety:}

The prevalence of generalized anxiety was $70.8 \%(n=1,189)$ among study participants during COVID 19 pandemic. Moderate and severe symptoms were present among $22 \%$ and $18 \%$ of the respondents.

Table 1 shows the baseline characteristics of participants as per the severity of generalized anxiety. The prevalence of severe GAD was significantly higher for females $(20 \%)$, individuals aged $\leq 39$ years $(18.5 \%)$, those who attained up to intermediate level of education (21.9\%), unemployed (28\%), those who were laid off due to pandemic situation (40.8\%), individuals with current $(37.4 \%)$ and previous history (36.5) of psychiatric illness, steroid users (26.1\%), and individuals with family members who have current (20.9\%) and past history (21.1\%) of psychiatric illnesses.

Participants who reported being highly worried about getting infected with corona virus when the first case and first death from corona virus was confirmed had higher proportion of severe generalized anxiety i.e. $35.2 \%$ and $32.4 \%$ respectively. Similarly, among those who reported excessive worrying about getting infected, when the nation level cases started increasing, $27.3 \%$ had severe and $24 \%$ had moderate symptoms of GAD.

A total of $27.7 \%$ individuals $(n=465)$ reported losing a near one as their biggest fear, of whom $21.5 \%$ had moderate and 15.7 had severe GAD. Among those with the intense fear of mental breakdown, approximately $30 \%$ had severe GAD.

The average perceived stress score among the population was $19.3(\mathrm{SD}= \pm 6.67)$. Majority had moderate perceived stress $(69.1 \%)$ and only one-seventh (14\%) had high perceived stress. More than half of the individuals with high perceived stress had generalized anxiety (55.5\%).

One-third of the population who strongly disagreed that the government is taking sufficient measures to prevent the spread of corona virus, had the symptoms of GAD. Likewise, $33 \%$ of the population had GAD, who strongly believed that no sufficient measures are taken by the health care facilities during COVID 19. Additionally, among those who were extremely anxious about the uncertainty of the situation, $46.1 \%$ had GAD.

Most of the individuals (56.2\%) were aware of 4 to 5 symptoms of corona-virus and among them $22 \%$ had moderate and $16 \%$ had severe GAD. Among those who know a case in family/ neighborhood, $19.8 \%$ were screened positive for severe GAD. Moreover, $30 \%$ of those who were suffering from one or more symptoms of corona virus at the time of survey had GAD.

\subsection{Generalized Anxiety and its predictors}

Ordinal logistic regression analysis was performed to measure the association between independent factors and generalized anxiety (Table 2). The findings suggest that the odds of GAD were approximately 3 times higher for respondents with current psychiatric illness (95\% Cl: 2.65-4.34). Respondents having severe anxiety about the uncertainty of situation had 4 times higher generalized anxiety (95\% Cl: $2.20-$ 
5.69) compared to those who were not at all anxious. Compared to those who had no fear of getting infected with corona virus, individuals with extreme fear had greater odds to have GAD (95\% Cl: 1.252.66). Likewise, the odds of GAD were 2.46 times for those who were extremely fearful of their loved ones getting infected with corona virus $(95 \% \mathrm{Cl}: 1.44-4.18)$ than those with no fear. Those respondents who were not indulged in any recreational activity at the time of lockdown were 1.27 times than those who were indulged to have GAD (95\% Cl: 1.05-1.54). Symptomatic individuals of COVID 19 had 1.69 higher odds of GAD than the recovered or previously infected (95\% Cl: 1.05-2.72).

Two interactions were found to be significant in the final model, indicating that males with high perceived stress had 22 times odds of GAD (95\% Cl: 9.48-47.46) than male with low perceived stress. Females with high perceived stress, on the other hand, were almost 30 times odds of having GAD than female with low perceived stress (Fig. 1). Moreover, the odds of GAD were 1.72 times greater (95\% Cl: 1.06-2.77) for individuals who frequently watch news related to COVID 19 during complete lockdown compared to those who rarely watch COVID 19 related news. Those who frequently watch COVID 19 related news during partial lockdown were 1.87 times ( $95 \% \mathrm{Cl}$ : $1.40-2.48$ ) more likely to have GAD than those who rarely watch news during complete lockdown (Fig. 2).

\section{Discussion}

This nationwide survey provides insight into the levels of anxiety exhibited by the Pakistani population during the first wave of the pandemic. Moderate and severe levels of generalized anxiety were found in $22 \%$ and $18 \%$ of Pakistan's general population, respectively. Various studies across the world reported similar rates of generalized anxiety $(19,31-33)$. Already existent psychological morbidities, financial constraints, fears, and worries encompassing COVID infection and the stress revolving around lockdowns and quarantine could be the plausible explanations for the alarming burden of generalized anxiety in Pakistani settings $(19,32)$.

The existent psychological illness was one of the factors influencing generalized anxiety in our study. Literature showed alignment with this finding and reported that individuals with persistent mental illness were more likely to have generalized anxiety(34). Inaccessibility to mental healthcare services amidst pandemic for treatment of existing mental illness might cause anxiety. Moreover, decreased coping mechanisms and exacerbation of symptoms of pre-existing psychological morbidity might also explain this association(34).

Another significant predictor of generalized anxiety in our study wasanxiety about uncertainty. Multiple studies were consistent with this finding, suggesting that intolerance towards uncertainty triggers massive fear and apprehension about the future in an individual, ultimately leading to disturbed mental wellbeing and anxiety $(35,36)$.

COVID related fears, including the fright of getting oneself and loved ones infected, were found to be contributing to generalized anxiety. Unavailability and unaffordability of healthcare services and fatal infectious outcomes were certain factors that reportedly instilled the fear of infection in individuals. This 
massive fear leads to hopelessness and maladaptive coping mechanisms, ultimately resulting in anxiety. Moreover, the fright of transmission of infection from oneself to loved ones could also elicit irrationalized thoughts and practices leading to anxiety $(14,37,38)$

Respondents who exhibited immense worry when initial cases of COVID 19 were reported were more likely to have generalized anxiety. Literature shows an agreement with this finding depicting that the first few cases of COVID 19 indeed instilled worry and concern among people leading to fright and ultimately anxiety. Worry that culminated into anxiety might be due to lack of knowledge of coronavirus and preventive measures, unequipped healthcare infrastructure, and unpreparedness to deal with COVID and its consequences during the initial phases $(39,40)$.

Our study findings further indicated that stressful quarantine/social isolation was another significant predictor of generalized anxiety. Literature highlighted that stressful quarantine was mostly correlated with financial constraints and feelings of loneliness and agitation. Financially unstable individuals were more concerned about their earning and expenses during the quarantine. Moreover, the helplessness of not being able to work to fulfill the expenditure could have also evoked stress and anxiety(37).

Indulgence in recreational activities was found to lower the likelihood of generalized anxiety in our study. Literature supported this association and reported that indulgence in recreational activities, especially during quarantine and social isolation increased coping and reduced reactivity to stress resulting in lower anxiety levels (41).

In our study, Respondents who were either infected or recovered from COVID or had similar symptoms exhibited generalized anxiety. One of the studies agreed with this finding and reported that anxiety levels were higher in suspected COVID patients. The threat of transmitting the virus to loved ones and fear of quarantine and death could be plausible explanations of this association(42).

One of the most significant key findings of this study was the interaction between gender and stress levels, indicating that females with higher perceived stress levels were more likely to have generalized anxiety than those with low-stress levels. This finding was consistent with the literature, which suggested that females with higher stress levels had a greater predisposition to anxiety. Cultural norms restrict females to externalize their stress and vent out their feelings and opinions. Moreover, hormonal changes also play a role in evoking anxiety in females. Additionally, increased responsibilities of household chores amidst pandemic could also trigger higher stress and anxiety levels in females(43).

In our study, frequent exposure to COVID related news during complete and partial lockdowns was associated with generalized anxiety. A similar finding was reported in a study in Bangladesh, indicating that individuals who are exposed to more than 4 hours of COVID related news on social and electronic media amidst complete and partial lockdowns experienced high levels of anxiety(44). Negative and overhyped news, along with myths and conspiracy theories, evokes stresses and fears. Furthermore, exposure to such news during a crisis situation like lockdowns could have intensified stress, ultimately leading to anxiety $(44,45)$. 
The present study reflected on multiple factors influencing the Pakistani population's psychological wellbeing amidst the COVID 19 pandemic, which should be catered to and proactively tackled by relevant authorities to prevent mental health crises. Sufficient sample size and use of validated tools ensured the rigor and power of this study. Limitations of this study include recall bias as specific questions were based on previous recall. Moreover, disproportionate gender and age groups in this study was another limitation. As this study was broadcasted via social media, mostly young and literate participants participated in this study, that is why only generalizable for internet users. Furthermore, the subjectivity of outcome was another limitation of this study.

\section{Conclusion}

To conclude, the present study suggests a substantial burden of moderate to severe GAD symptoms in the general population amidst the first wave of the COVID 19 pandemic. The conversion of initial GAD symptoms into established mental disorder will hamper the country's social and economic recovery once the pandemic flattens; hence establishing appropriate and low-threshold interventions by the government to mitigate the foreseen mental health crises is a compulsion. Moreover, this study also identified certain groups with social and economic challenges to be more vulnerable to the psychological impact of COVID 19; therefore, specific and customized interventions should be curated to cater to these strata. Policies should also be curated for responsible journalism and communication of relevant news via various media platforms as the present study suggested a greater frequency of COVID-related news to be associated with anxiety symptoms.

\section{References}

1. Cordaro M, Grigsby TJ, Howard JT, Deason RG, Haskard-Zolnierek K, Howard K. Pandemic-Specific Factors Related to Generalized Anxiety Disorder during the Initial COVID-19 Protocols in the United States. 2021:1-21.

2. Carter C, Thi Lan Anh N, Notter J. COVID-19 disease: perspectives in low- and middle-income countries. Clinics in Integrated Care. 2020;1:100005-.

3. Noreen N, Dil S, Niazi S, Naveed I, Khan N, Khan F, et al. COVID 19 pandemic \& Pakistan; limitations and gaps. Global Biosecurity. 2020;1(4).

4. Pakistan Go. Pakistan Statistics 2021 [23/2/2021]. Available from: https://covid.gov.pk/.

5. Hall RC, MJ C. The 1995 Kikwit Ebola outbreak: lessons hospitals and physicians can apply to future viral epidemics. General hospital psychiatry. 2008;30(5):446-52.

6. Van Bortel T, Basnayake A, Wurie F, Jambai M, Koroma AS, Muana AT, et al. Psychosocial effects of an Ebola outbreak at individual, community and international levels. Bull World Health Organ. 2016;94(3):210-4.

7. Maunder R, Hunter J, Vincent L, Bennett J, Peladeau N, Leszcz M, et al. The immediate psychological and occupational impact of the 2003 SARS outbreak in a teaching hospital. Cmaj. 
2003;168(10):1245-51.

8. Leung GM, Lam TH, Ho LM, Ho S, Chan B, Wong I, et al. The impact of community psychological responses on outbreak control for severe acute respiratory syndrome in Hong Kong. 2003;57(11):857-63.

9. Jeong H, Yim HW, Song Y-J, Ki M, Min J-A, Cho J, et al. Mental health status of people isolated due to Middle East Respiratory Syndrome. 2016;38.

10. Saladino V, Algeri D, Auriemma V. The Psychological and Social Impact of Covid-19: New Perspectives of Well-Being. Frontiers in Psychology. 2020;11(2550).

11. 11., Constable P, Hussain S. Pakistan locks down province, bans international flights as coronavirus spreads. Washington Post. March 2020.

12. Shafi M, Liu J, Ren W. Impact of COVID-19 pandemic on micro, small, and medium-sized Enterprises operating in Pakistan. Research in Globalization. 2020;2:100018.

13. Mamun MA, Ullah I. COVID-19 suicides in Pakistan, dying off not COVID-19 fear but poverty? - The forthcoming economic challenges for a developing country. Brain Behav Immun. 2020;87:163-6.

14. Wang C, Pan R, Wan X, Tan Y, Xu L, Ho CS, et al. Immediate Psychological Responses and Associated Factors during the Initial Stage of the 2019 Coronavirus Disease (COVID-19) Epidemic among the General Population in China. Int J Environ Res Public Health. 2020;17(5).

15. Colbourn T. COVID-19: extending or relaxing distancing control measures. The Lancet Public Health.

16. Huang Y, Zhao N. Generalized anxiety disorder, depressive symptoms and sleep quality during COVID-19 epidemic in China: a web-based cross-sectional survey. medRxiv. 2020:2020.02.19.20025395.

17. Islam MS, Ferdous MZ, Potenza MN. Panic and generalized anxiety during the COVID-19 pandemic among Bangladeshi people: An online pilot survey early in the outbreak. J Affect Disord. 2020;276:30-7.

18. Association. AP. Diagnostic and Statistical Manual of Mental Disorders. 5th ed. Washington, DC; 2013.

19. Bäuerle A, Teufel M, Musche V, Weismüller B, Kohler H, Hetkamp M, et al. Increased generalized anxiety, depression and distress during the COVID-19 pandemic: a cross-sectional study in Germany. Journal of Public Health. 2020;42(4):672-8.

20. Fisher JR, Tran TD, Hammarberg K, Sastry J, Nguyen H, Rowe H, et al. Mental health of people in Australia in the first month of COVID-19 restrictions: a national survey. Medical journal of Australia. 2020;213(10):458-64.

21. Aloraini MI, Mohammad SM, Hejazi MS, Hejazi MS, Alharbi AA, Al-Harthi KA, et al. Prevalence of generalized anxiety disorder among Saudi youth during COVID-19 pandemic in Saudi Arabia. IJMDC. 2020;4(12):2322-7.

22. Salari N, Hosseinian-Far A, Jalali R, Vaisi-Raygani A, Rasoulpoor S, Mohammadi M, et al. Prevalence of stress, anxiety, depression among the general population during the COVID-19 pandemic: a 
systematic review and meta-analysis. Globalization and Health. 2020;16(1):57.

23. Arshad AR, Islam F. COVID-19 and Anxiety amongst Doctors: A Pakistani Perspective. Journal of the College of Physicians and Surgeons-Pakistan: JCPSP. 2020;30(10):106-9.

24. Salman M, Asif N, Mustafa ZU, Khan TM, Shehzadi N, Hussain K, et al. Psychological impact of COVID-19 on Pakistani university students and how they are coping. Medrxiv. 2020.

25. Asim SS, Ghani S, Ahmed M, Asim A, Qureshi AFK. Assessing Mental Health of Women Living in Karachi During the Covid-19 Pandemic. Frontiers in Global Women's Health. 2021;1(24).

26. Sandesh R, Shahid W, Dev K, Mandhan N, Shankar P, Shaikh A, et al. Impact of COVID-19 on the mental health of healthcare professionals in Pakistan. Cureus. 2020;12(7).

27. Hendriks SM, Spijker J, Licht CMM, Hardeveld F, de Graaf R, Batelaan NM, et al. Long-term disability in anxiety disorders. BMC Psychiatry. 2016;16(1):248.

28. Al-Rabiaah A, Temsah M-H, Al-Eyadhy AA, Hasan GM, Al-Zamil F, Al-Subaie S, et al. Middle East Respiratory Syndrome-Corona Virus (MERS-CoV) associated stress among medical students at a university teaching hospital in Saudi Arabia. Journal of Infection and Public Health. 2020.

29. Taylor J. Psychometric Analysis of the Ten-Item Perceived Stress Scale. Psychological assessment. 2014;27.

30. Elizarrarás-Rivas J, Vargas-Mendoza JE, Mayoral-García M, Matadamas-Zarate C, Elizarrarás-Cruz A, Taylor M, et al. Psychological response of family members of patients hospitalised for influenza A/H1N1 in Oaxaca, Mexico. BMC psychiatry. 2010;10:104-.

31. Naser AY, Dahmash EZ, Al-Rousan R, Alwafi H, Alrawashdeh HM, Ghoul I, et al. Mental health status of the general population, healthcare professionals, and university students during 2019 coronavirus disease outbreak in Jordan: a cross-sectional study. 2020.

32. Maroufizadeh S, Pourshaikhian M, Pourramzani A, Sheikholeslami F, Moghadamnia MT, Alavi SA. Prevalence of Anxiety and Depression in General Population of Iran during the COVID-19 Pandemic: A Web-Based Cross-Sectional Study. 2020.

33. Pieh C, Budimir S, Probst T. The effect of age, gender, income, work, and physical activity on mental health during coronavirus disease (COVID-19) lockdown in Austria. Journal of Psychosomatic Research. 2020;136:110186.

34. Özdin S, Bayrak Özdin Ş. Levels and predictors of anxiety, depression and health anxiety during COVID-19 pandemic in Turkish society: The importance of gender. Int J Soc Psychiatry. 2020;66(5):504-11.

35. Seco Ferreira DC, Oliveira WL, Costa Delabrida ZN, Faro A, Cerqueira-Santos EJSP. Intolerance of uncertainty and mental health in Brazil during the Covid-19 pandemic. 2020;27(1):62-9.

36. Bakioğlu F, Korkmaz O, Ercan HJIJoMH, Addiction. Fear of COVID-19 and Positivity: Mediating Role of Intolerance of Uncertainty, Depression, Anxiety, and Stress. 2020:1.

37. Lei L, Huang X, Zhang S, Yang J, Yang L, Xu M. Comparison of Prevalence and Associated Factors of Anxiety and Depression Among People Affected by versus People Unaffected by Quarantine During 
the COVID-19 Epidemic in Southwestern China. Med Sci Monit. 2020;26:e924609-e.

38. Mertens G, Gerritsen L, Duijndam S, Salemink E, Engelhard IM. Fear of the coronavirus (COVID-19): Predictors in an online study conducted in March 2020. Journal of Anxiety Disorders. 2020;74:102258.

39. Roy D, Tripathy S, Kar SK, Sharma N, Verma SK, Kaushal V. Study of knowledge, attitude, anxiety \& perceived mental healthcare need in Indian population during COVID-19 pandemic. Asian J Psychiatr. 2020;51:102083-.

40. Varshney M, Parel JT, Raizada N, Sarin SK. Initial psychological impact of COVID-19 and its correlates in Indian Community: An online (FEEL-COVID) survey. PLOS ONE. 2020;15(5):e0233874.

41. Khan AH, Sultana MS, Hossain S, Hasan MT, Ahmed HU, Sikder MT. The impact of COVID-19 pandemic on mental health \& wellbeing among home-quarantined Bangladeshi students: A crosssectional pilot study. J Affect Disord. 2020;277:121-8.

42. Dai L-L, Wang X, Jiang T-C, Li P-F, Wang Y, Wu S-J, et al. Anxiety and depressive symptoms among COVID-19 patients in Jianghan Fangcang Shelter Hospital in Wuhan, China. PLOS ONE. 2020;15(8):e0238416.

43. Zhang C, Peng D, Lv L, Zhuo K, Yu K, Shen T, et al. Individual Perceived Stress Mediates Psychological Distress in Medical Workers During COVID-19 Epidemic Outbreak in Wuhan. 2020;16:2529.

44. Hossain MT, Ahammed B, Chanda SK, Jahan N, Ela MZ, Islam MN. Social and electronic media exposure and generalized anxiety disorder among people during COVID-19 outbreak in Bangladesh: A preliminary observation. PLOS ONE. 2020;15(9):e0238974.

45. Rahman MA, Hoque N, Alif SM, Salehin M, Islam SMS, Banik B, et al. Factors associated with psychological distress, fear and coping strategies during the COVID-19 pandemic in Australia. Globalization and Health. 2020;16(1):95.

\section{Tables}

Table I: Descriptive Statistics of participants stratified by main outcome (Generalized Anxiety Disorder) 


\begin{tabular}{|c|c|c|c|c|c|}
\hline \multirow[t]{2}{*}{ Baseline characteristics } & \multirow{2}{*}{$\begin{array}{c}\text { Total } \\
\mathrm{N}=1679 \\
\mathrm{n}(\%)\end{array}$} & \multicolumn{4}{|c|}{$\begin{array}{c}\text { Generalized Anxiety Disorder } \\
\mathrm{n}(\%)\end{array}$} \\
\hline & & $\begin{array}{c}\text { No } \\
\text { anxiety } \\
490 \text { (29) }\end{array}$ & $\begin{array}{c}\text { Mild } \\
\text { anxiety } \\
523(31)\end{array}$ & 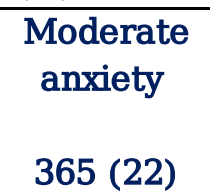 & $\begin{array}{c}\text { Severe } \\
\text { anxiety }\end{array}$ \\
\hline \multicolumn{6}{|l|}{ SOCIO-DEMOGRAPHIC: } \\
\hline $\begin{array}{l}\text { Age (years) } \\
\text { - } 15-24 \\
\text { - } 25-39 \\
\text { - } 40-49 \\
\text { - } 50 \text { and above }\end{array}$ & $\begin{array}{c}29.41 \pm \\
9.60^{*} \\
\\
619(36.87) \\
841(50.09) \\
130(7.74) \\
89(5.30)\end{array}$ & $\begin{array}{c}31.2 \pm \\
11.2^{*} \\
\\
168 \\
(27.1) \\
228 \\
(27.1) \\
53 \\
(40.8) \\
41 \\
(46.1) \\
\end{array}$ & $\begin{array}{c}28.8 \pm \\
8.8^{*} \\
\\
195 \\
(31.5) \\
268 \\
(31.9) \\
38(29.2) \\
22(24.7)\end{array}$ & $\begin{array}{l}28.5 \pm 8.7^{*} \\
139(22.5) \\
189(22.5) \\
22(16.9) \\
15(16.8)\end{array}$ & $\begin{array}{l}28.3 \pm 8.6^{*} \\
117(18.9) \\
156(18.5) \\
17(13.1) \\
11(12.4)\end{array}$ \\
\hline $\begin{array}{l}\text { Gender } \\
\text { - Male } \\
\text { - Female }\end{array}$ & $\begin{array}{l}458(27.78) \\
1221(72.72)\end{array}$ & $\begin{array}{c}163 \\
(35.6) \\
327 \\
(26.8)\end{array}$ & $\begin{array}{c}165 \\
(36.0) \\
358 \\
(29.3)\end{array}$ & $\begin{array}{c}72(15.7) \\
293(23.9)\end{array}$ & $\begin{array}{l}58(12.7) \\
243(20.0)\end{array}$ \\
\hline $\begin{array}{l}\text { Education status } \\
\text { - Up to intermediate } \\
\text { - Graduate } \\
\text { - Post graduate }\end{array}$ & $\begin{array}{l}269(16.02) \\
727(43.30) \\
683(40.68)\end{array}$ & $\begin{array}{c}60 \\
(22.3) \\
217 \\
(29.8) \\
213 \\
(31.2)\end{array}$ & $\begin{array}{c}77(28.6) \\
227 \\
(31.2) \\
219 \\
(32.1)\end{array}$ & $\begin{array}{c}73(27.1) \\
155(21.3) \\
137(20.0)\end{array}$ & $\begin{array}{c}59(21.9) \\
128(17.6) \\
114(16.7)\end{array}$ \\
\hline $\begin{array}{l}\text { Employment status } \\
\text { - Employed } \\
\text { - Self-employed } \\
\text { - Homemaker } \\
\text { - Student } \\
\text { - Unemployed }\end{array}$ & $\begin{array}{c}685(40.80) \\
160(9.53) \\
235(14) \\
481(28.65) \\
118(7.03)\end{array}$ & $\begin{array}{c}236 \\
(34.5) \\
41 \\
(25.6) \\
68 \\
(28.9) \\
126 \\
(26.2) \\
19 \\
(16.1)\end{array}$ & $\begin{array}{c}216 \\
(31.5) \\
54(33.8) \\
65(27.7) \\
150 \\
(31.2) \\
38(32.2)\end{array}$ & $\begin{array}{c}132(19.3) \\
36(22.5) \\
51(21.7) \\
118(24.5) \\
28(23.7)\end{array}$ & $\begin{array}{l}101(14.7) \\
29(18.1) \\
51(21.7) \\
87(18.1) \\
33(28.0)\end{array}$ \\
\hline $\begin{array}{l}\text { Working status } \\
\text { - Student } \\
\text { - Working from home } \\
\text { - Household chores } \\
\text { - Going to workplace } \\
\text { - Laid-off } \\
\text { - Relaxing }\end{array}$ & $\begin{array}{c}474(28.2) \\
516(30.7) \\
\\
269(16.0) \\
264(15.7) \\
49(2.9) \\
107(6.4)\end{array}$ & $\begin{array}{c}119 \\
(25.1) \\
157 \\
(30.4) \\
\\
65 \\
(24.2) \\
99 \\
(37.5) \\
7(14.3)\end{array}$ & $\begin{array}{c}154 \\
(32.5) \\
170 \\
(33.0) \\
81(30.1) \\
79(29.9) \\
13(26.5) \\
26(24.3)\end{array}$ & $\begin{array}{c}113(23.8) \\
112(21.7) \\
65(24.2) \\
46(17.4) \\
9(18.4) \\
20(18.7)\end{array}$ & $\begin{array}{l}88(18.6) \\
77(14.9) \\
58(21.5) \\
40(15.2) \\
20(40.8) \\
18(16.8)\end{array}$ \\
\hline
\end{tabular}




\begin{tabular}{|c|c|c|c|c|c|}
\hline & & $\begin{array}{c}43 \\
(40.2)\end{array}$ & & & \\
\hline $\begin{array}{l}\text { Currently having any psychiatric illness } \\
\text { - Yes } \\
\text { - Don't Know }\end{array}$ & $\begin{array}{l}409(24.36) \\
342(20.3)\end{array}$ & $\begin{array}{c}41 \\
(10.0) \\
53 \\
(15.5) \\
\end{array}$ & $\begin{array}{c}106 \\
(25.9) \\
106 \\
(31.0)\end{array}$ & $\begin{array}{l}109(26.7) \\
107(31.3)\end{array}$ & $\begin{array}{c}153(37.4) \\
76(22.2)\end{array}$ \\
\hline \multicolumn{6}{|l|}{ WORRIEDNESS: } \\
\hline $\begin{array}{l}\text { Getting infected when first case confirmed } \\
\text { - Worried a lot } \\
\text { - Worried little bit } \\
\text { - Never thought about it }\end{array}$ & $\begin{array}{l}338(20.13) \\
507(30.20) \\
834(49.67)\end{array}$ & $\begin{array}{c}49 \\
(14.5) \\
149 \\
(29.4) \\
292 \\
(35.0)\end{array}$ & $\begin{array}{c}82 \\
(24.3) \\
178 \\
(35.1) \\
263 \\
(31.5)\end{array}$ & $\begin{array}{c}88(26.0) \\
104(20.5) \\
173(20.7)\end{array}$ & $\begin{array}{c}119(35.2) \\
76(15.0) \\
106(12.7)\end{array}$ \\
\hline $\begin{array}{l}\text { Getting infected when first death } \\
\text { - Worried a lot } \\
\text { - Worried little bit } \\
\text { - Never thought about it }\end{array}$ & $\begin{array}{l}407(24.24) \\
579(34.48) \\
693(41.27)\end{array}$ & $\begin{array}{l}64 \\
(15.7) \\
176 \\
(30.4) \\
250 \\
(36.1)\end{array}$ & $\begin{array}{l}103 \\
(25.3) \\
207 \\
(35.8) \\
213 \\
(30.7)\end{array}$ & $\begin{array}{l}108(26.5) \\
118(20.4) \\
139(20.1)\end{array}$ & $\begin{array}{c}132(32.4) \\
78(13.5) \\
91(13.1)\end{array}$ \\
\hline Imposition of lockdown & $813(48.42)$ & $\begin{array}{c}198 \\
(24.4)\end{array}$ & $\begin{array}{c}267 \\
(32.8)\end{array}$ & $194(23.9)$ & $154(18.9)$ \\
\hline \multicolumn{6}{|l|}{ FEAR: } \\
\hline $\begin{array}{l}\text { Getting infected with corona virus } \\
\text { - No fear } \\
\text { - Slight fear } \\
\text { - A lot of fear }\end{array}$ & $\begin{array}{l}231(13.76) \\
807(48.06) \\
641(38.18)\end{array}$ & $\begin{array}{l}110 \\
(47.7) \\
294 \\
(36.4) \\
86 \\
(13.4)\end{array}$ & $\begin{array}{c}51(22.1) \\
290 \\
(35.9) \\
182 \\
(28.4)\end{array}$ & $\begin{array}{c}37(16.0) \\
148(18.3) \\
180(28.1)\end{array}$ & $\begin{array}{c}33(14.3) \\
75(9.3) \\
193(30.1)\end{array}$ \\
\hline $\begin{array}{l}\text { Loved ones getting infected with corona } \\
\text { virus } \\
\text { - No fear } \\
\text { - Slight fear } \\
\text { - A lot of fear }\end{array}$ & $\begin{array}{c}79(4.71) \\
318(18.94) \\
1282 \\
(76.35)\end{array}$ & $\begin{array}{c}45 \\
(57.0) \\
154 \\
(48.4) \\
291 \\
(22.7)\end{array}$ & $\begin{array}{c}22(27.8) \\
86(27.0) \\
415 \\
(32.4)\end{array}$ & $\begin{array}{c}6(7.6) \\
57(17.9) \\
302(23.5)\end{array}$ & $\begin{array}{c}6(7.6) \\
21(6.6) \\
274(21.4)\end{array}$ \\
\hline $\begin{array}{l}\text { Social isolation/distancing } \\
\text { - No fear } \\
\text { - Slight fear } \\
\text { - A lot of fear }\end{array}$ & $\begin{array}{l}503(29.96) \\
608(36.21) \\
568(33.83)\end{array}$ & $\begin{array}{c}213 \\
(42.3) \\
177 \\
(29.1)\end{array}$ & $\begin{array}{c}150 \\
(29.8) \\
218 \\
(35.9)\end{array}$ & $\begin{array}{c}76(15.1) \\
125(20.5) \\
164(28.9)\end{array}$ & $\begin{array}{c}64(12.7) \\
88(14.5) \\
149(26.2)\end{array}$ \\
\hline
\end{tabular}




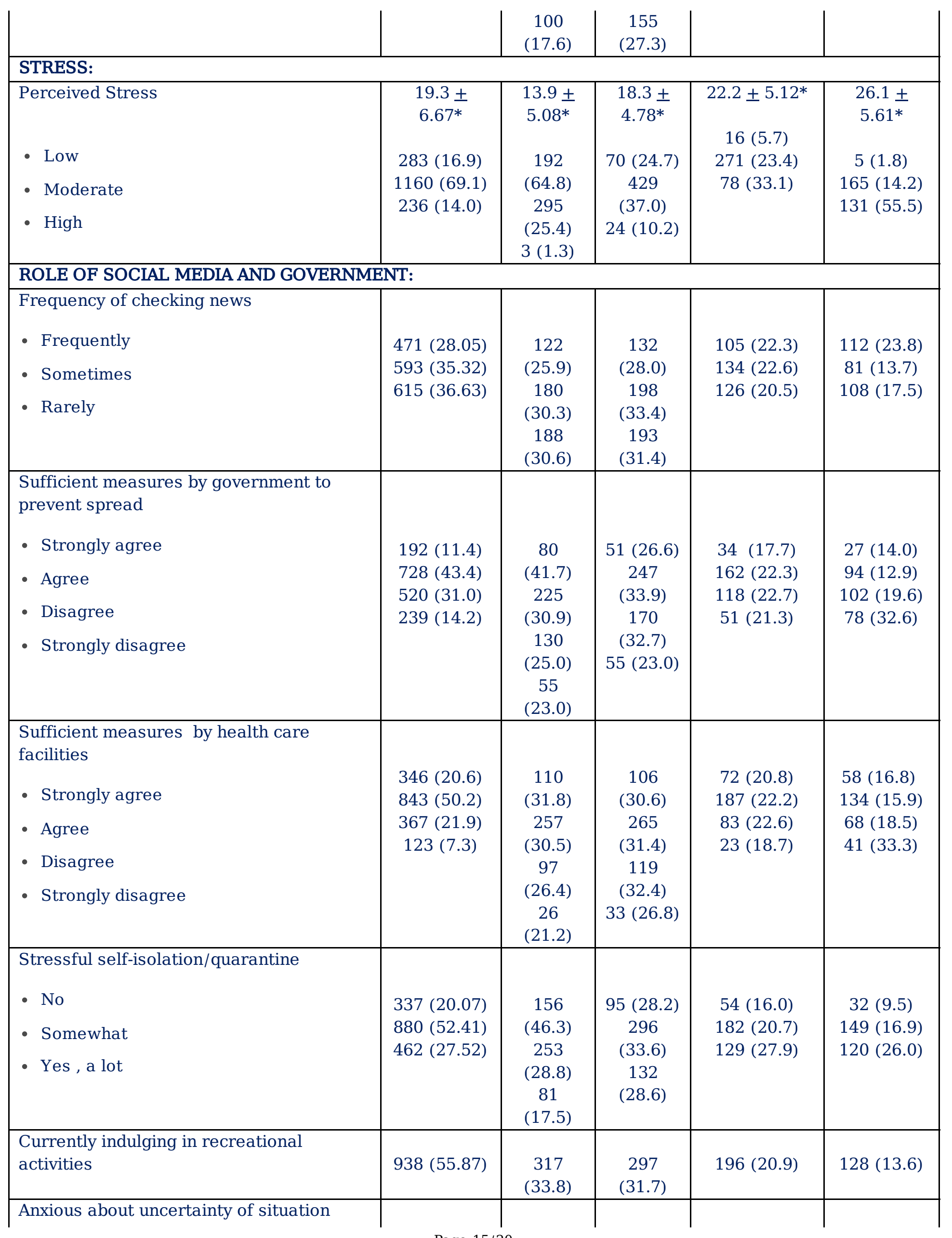




\begin{tabular}{|c|c|c|c|c|c|}
\hline $\begin{array}{l}\text { - Slightly anxious } \\
\text { - } \text { Moderately anxious } \\
\text { - Severely anxious }\end{array}$ & $\begin{array}{c}668(39.8) \\
605(36.03) \\
267(15.90)\end{array}$ & $\begin{array}{c}282 \\
(42.2) \\
114 \\
(18.8) \\
22(8.2)\end{array}$ & $\begin{array}{c}219 \\
(32.8) \\
223 \\
(36.9) \\
49(18.4)\end{array}$ & $\begin{array}{l}116(17.4) \\
158(26.1) \\
73(27.3)\end{array}$ & $\begin{array}{c}51(7.6) \\
110(18.2) \\
123(46.1)\end{array}$ \\
\hline $\begin{array}{l}\text { Phases of lockdown } \\
\text { - Complete lockdown } \\
\text { - Smart lockdown }\end{array}$ & $\begin{array}{c}417(24.84) \\
1262 \\
(75.16)\end{array}$ & $\begin{array}{c}164 \\
(39.3) \\
\\
326 \\
(25.8) \\
\end{array}$ & $\begin{array}{c}123 \\
(29.5) \\
\\
400 \\
(31.7) \\
\end{array}$ & $\begin{array}{l}79(18.9) \\
286(22.7)\end{array}$ & $\begin{array}{l}51(12.2) \\
250(19.8)\end{array}$ \\
\hline KNOWLEDGE: & & & & & \\
\hline $\begin{array}{l}\text { Current health status } \\
\text { - Currently no symptoms of Corona } \\
\text { - Infected/recovered from Corona } \\
\text { - Currently one of more symptoms }\end{array}$ & $\begin{array}{c}1484 \\
(88.39) \\
127(7.6) \\
68(4.1)\end{array}$ & $\begin{array}{c}454 \\
(30.6) \\
\\
25 \\
(19.7) \\
\\
11 \\
(16.2) \\
\end{array}$ & $\begin{array}{c}465 \\
(31.3) \\
39(30.7) \\
19(27.9)\end{array}$ & $\begin{array}{l}309(20.8) \\
39(30.7) \\
17(25.0)\end{array}$ & $\begin{array}{l}256(17.3) \\
24(18.9) \\
21(30.9)\end{array}$ \\
\hline $\begin{array}{l}\text { Knowledge regarding symptoms }{ }^{1} \\
\text { - Poor } \\
\text { - Satisfactory } \\
\text { - Good }\end{array}$ & $\begin{array}{l}233(13.88) \\
944(56.22) \\
502(29.90)\end{array}$ & $\begin{array}{c}80 \\
(34.3) \\
281 \\
(29.8) \\
129 \\
(25.7) \\
\end{array}$ & $\begin{array}{c}69(29.6) \\
298 \\
(31.6) \\
156 \\
(31.1)\end{array}$ & $\begin{array}{l}53(22.8) \\
210(22.2) \\
102(20.3)\end{array}$ & $\begin{array}{l}31(13.3) \\
155(16.4) \\
115(22.9)\end{array}$ \\
\hline $\begin{array}{l}\text { Knowledge regarding prevention }{ }^{2} \\
\text { - Poor } \\
\text { - Satisfactory } \\
\text { - Good }\end{array}$ & $\begin{array}{c}93(5.54) \\
644(38.36) \\
942(56.10)\end{array}$ & $\begin{array}{c}23 \\
(24.7) \\
193 \\
(30.0) \\
274 \\
(29.1)\end{array}$ & $\begin{array}{c}31(33.3) \\
208 \\
(32.3) \\
284 \\
(30.2)\end{array}$ & $\begin{array}{l}27(29.0) \\
128(19.9) \\
210(22.3)\end{array}$ & $\begin{array}{l}12(12.9) \\
115(17.9) \\
174(18.5)\end{array}$ \\
\hline \multicolumn{6}{|c|}{$\begin{array}{l}* \text { Mean } \pm \text { SD } \\
1 \text { Poor: Aware of at least } 3 \text { symptoms methods, Satisfactory: } 4 \text { to } 5 \text { symptoms methods, Good: } 6 \text { to } 7 \text { symptoms } \\
2 \text { Poor: Aware of at least } 3 \text { prevention methods, Satisfactory: } 4 \text { to } 7 \text { prevention methods, Good: All prevention } \\
\text { methods. }\end{array}$} \\
\hline
\end{tabular}

Table II: Ordinal logistic multivariable regression model reporting adjusted odds ratio along $1 \%$ 
Confidence interval of factors associated with Generalized Anxiety Disorder among $s$ of Pakistan 


\begin{tabular}{|c|c|c|c|c|c|}
\hline Characteristics & $\begin{array}{c}\text { Crude } \\
\text { Odds Ratio }\end{array}$ & $\begin{array}{r}9 \\
\text { Conf } \\
\text { Int }\end{array}$ & $\begin{array}{l}\% \\
\text { dence } \\
\text { rval }\end{array}$ & $\begin{array}{c}\text { Adjusted } \\
\text { Odds Ratio }\end{array}$ & $\begin{array}{c}\text { 95\% Confidence } \\
\text { Interval }\end{array}$ \\
\hline $\begin{array}{l}\text { - Moderate } \\
\text { - High }\end{array}$ & $\begin{array}{c}6.49 \\
58.69\end{array}$ & $\begin{array}{r}4.94 \\
40.40\end{array}$ & $\begin{array}{l}8.54 \\
85.34\end{array}$ & - & - \\
\hline $\begin{array}{l}\text { Participant's current Psychiatric Illness } \\
\text { - Don't Know } \\
\text { - Yes }\end{array}$ & $\begin{array}{l}3.68 \\
6.46\end{array}$ & $\begin{array}{l}2.92 \\
5.15\end{array}$ & $\begin{array}{l}4.63 \\
8.11\end{array}$ & $\begin{array}{l}2.07 \\
3.40\end{array}$ & $\begin{array}{l}1.62-2.65 \\
2.65-4.34\end{array}$ \\
\hline $\begin{array}{l}\text { Anxiousness about uncertainty } \\
\text { - Slightly anxious } \\
\text { - Moderately anxious } \\
\text { - Severely anxious }\end{array}$ & $\begin{array}{c}1.25 \\
3.34 \\
11.50\end{array}$ & $\begin{array}{c}0.88 \\
2.33 \\
7.65\end{array}$ & $\begin{array}{c}1.79 \\
4.78 \\
17.29\end{array}$ & $\begin{array}{l}1.02 \\
1.65 \\
3.54\end{array}$ & $\begin{array}{l}0.68-1.54 \\
1.08-2.53 \\
2.20-5.69\end{array}$ \\
\hline $\begin{array}{l}\text { Fear of getting infected with Corona } \\
\text { - Slight Fear } \\
\text { - A lot of Fear }\end{array}$ & $\begin{array}{l}1.21 \\
4.36\end{array}$ & $\begin{array}{l}0.91 \\
3.26\end{array}$ & $\begin{array}{l}1.60 \\
5.85\end{array}$ & $\begin{array}{l}0.96 \\
1.82\end{array}$ & $\begin{array}{l}0.69-1.35 \\
1.25-2.66\end{array}$ \\
\hline $\begin{array}{l}\text { Fear of Loved ones getting infected with } \\
\text { - Slight Fear } \\
\text { - A lot of Fear }\end{array}$ & $\begin{array}{l}1.47 \\
4.40\end{array}$ & $\begin{array}{l}0.91 \\
2.82\end{array}$ & $\begin{array}{l}2.36 \\
6.86\end{array}$ & $\begin{array}{l}1.85 \\
2.46\end{array}$ & $\begin{array}{l}1.07-3.21 \\
1.44-4.18\end{array}$ \\
\hline $\begin{array}{l}\text { Worrying when First Case reported } \\
\text { - Worried little bit } \\
\text { - Worried a lot }\end{array}$ & $\begin{array}{l}1.19 \\
3.38\end{array}$ & $\begin{array}{l}1.98 \\
2.67\end{array}$ & $\begin{array}{l}1.46 \\
4.27\end{array}$ & $\begin{array}{l}0.87 \\
1.46\end{array}$ & $\begin{array}{l}0.69-1.09 \\
1.11-1.93\end{array}$ \\
\hline $\begin{array}{l}\text { Stressful Quarantine/social isolation } \\
\text { - Somewhat } \\
\text { - Yes, a lot }\end{array}$ & $\begin{array}{l}1.99 \\
3.70\end{array}$ & $\begin{array}{l}1.58 \\
2.89\end{array}$ & $\begin{array}{l}2.52 \\
4.81\end{array}$ & $\begin{array}{l}1.72 \\
1.74\end{array}$ & $\begin{array}{l}1.32-2.23 \\
1.30-2.32\end{array}$ \\
\hline $\begin{array}{l}\text { Indulgence in Recreational activities } \\
\text { - No }\end{array}$ & 1.70 & 1.42 & 2.02 & 1.27 & $1.05-1.54$ \\
\hline $\begin{array}{l}\text { Phases of lockdown } \\
\text { - Smart lockdown }\end{array}$ & 1.76 & 1.43 & 1.25 & 1. & - \\
\hline $\begin{array}{l}\text { Gender } \\
\text { - Female }\end{array}$ & 1.69 & 1.39 & 2.06 & - & - \\
\hline $\begin{array}{l}\text { Current health status } \\
\text { - Infected or recovered from Corona } \\
\text { - Currently symptomatic }\end{array}$ & $\begin{array}{l}1.51 \\
2.15\end{array}$ & $\begin{array}{l}1.10 \\
1.38\end{array}$ & $\begin{array}{l}2.07 \\
3.33\end{array}$ & $\begin{array}{l}1.19 \\
1.69\end{array}$ & $\begin{array}{l}1.83-1.69 \\
1.05-2.72\end{array}$ \\
\hline
\end{tabular}




\begin{tabular}{|c|c|c|c|c|c|}
\hline $\begin{array}{l}\text { Frequency of watching COVID } 19 \text { related news } \\
\text { - Sometimes } \\
\text { - Frequently }\end{array}$ & $\begin{array}{l}0.93 \\
1.37\end{array}$ & $\begin{array}{l}0.75 \\
1.10\end{array}$ & $\begin{array}{l}1.13 \\
1.70\end{array}$ & - & - \\
\hline \multicolumn{6}{|l|}{ Gender and Perceived stress } \\
\hline $\begin{array}{l}\text { Male } \\
\text { - Low stress (ref) } \\
\text { - Moderate stress } \\
\text { - High stress } \\
\text { Female } \\
\text { - Low stress (ref) } \\
\text { - Moderate stress } \\
\text { - High stress }\end{array}$ & $\begin{array}{l}- \\
- \\
-\end{array}$ & & $\begin{array}{l}- \\
- \\
- \\
- \\
- \\
-\end{array}$ & $\begin{array}{c}- \\
3.00 \\
22.19 \\
- \\
5.31 \\
29.96\end{array}$ & $\begin{aligned} & - \\
1.80 & -4.71 \\
9.48 & -47.46 \\
& \\
& - \\
3.69 & -7.61 \\
20.02 & -44.46\end{aligned}$ \\
\hline \multicolumn{6}{|c|}{ Phases of lockdown and Frequency of watching COVID 19 related news ${ }^{\wedge}$} \\
\hline $\begin{array}{l}\text { Complete lockdown } \\
\text { - Rarely watching COVID } 19 \text { news (ref) } \\
\text { - Sometimes watching COVID } 19 \text { news } \\
\text { - Frequently watching COVID } 19 \text { News } \\
\text { Smart Lockdown } \\
\text { - Rarely watching COVID } 19 \text { news } \\
\text { - Sometimes watching COVID } 19 \text { news } \\
\text { - Frequently watching COVID } 19 \text { News }\end{array}$ & - & & $\begin{array}{l}- \\
-\end{array}$ & $\begin{array}{l}- \\
1.09 \\
1.72 \\
1.82 \\
1.56\end{array}$ & $\begin{array}{l}- \\
0.67-1.80 \\
1.06-2.77 \\
1.20-2.74 \\
1.13-2.14 \\
1.40-2.48\end{array}$ \\
\hline
\end{tabular}

\section{Figures}




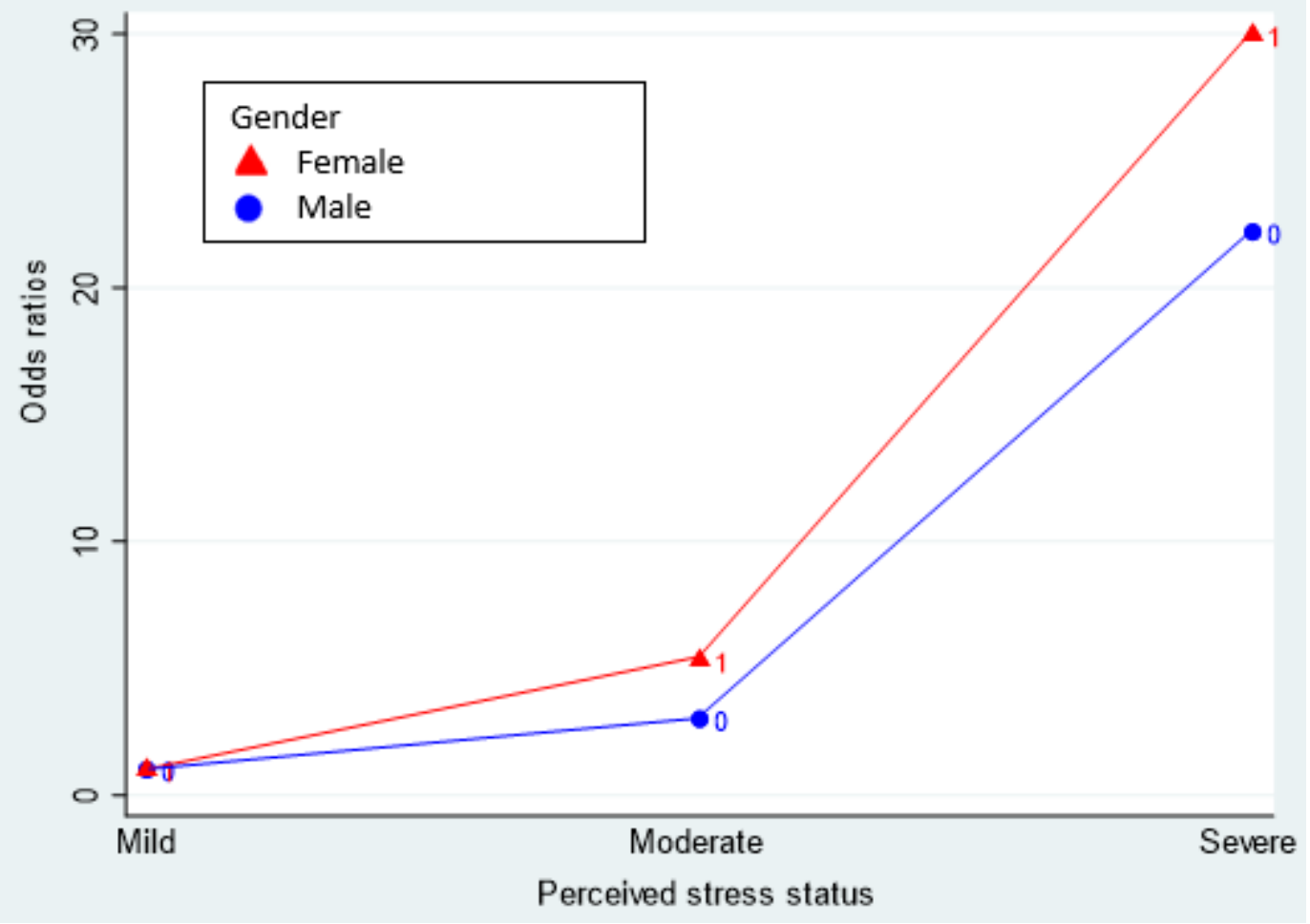

Figure 1

Interaction between perceived stress levels and gender

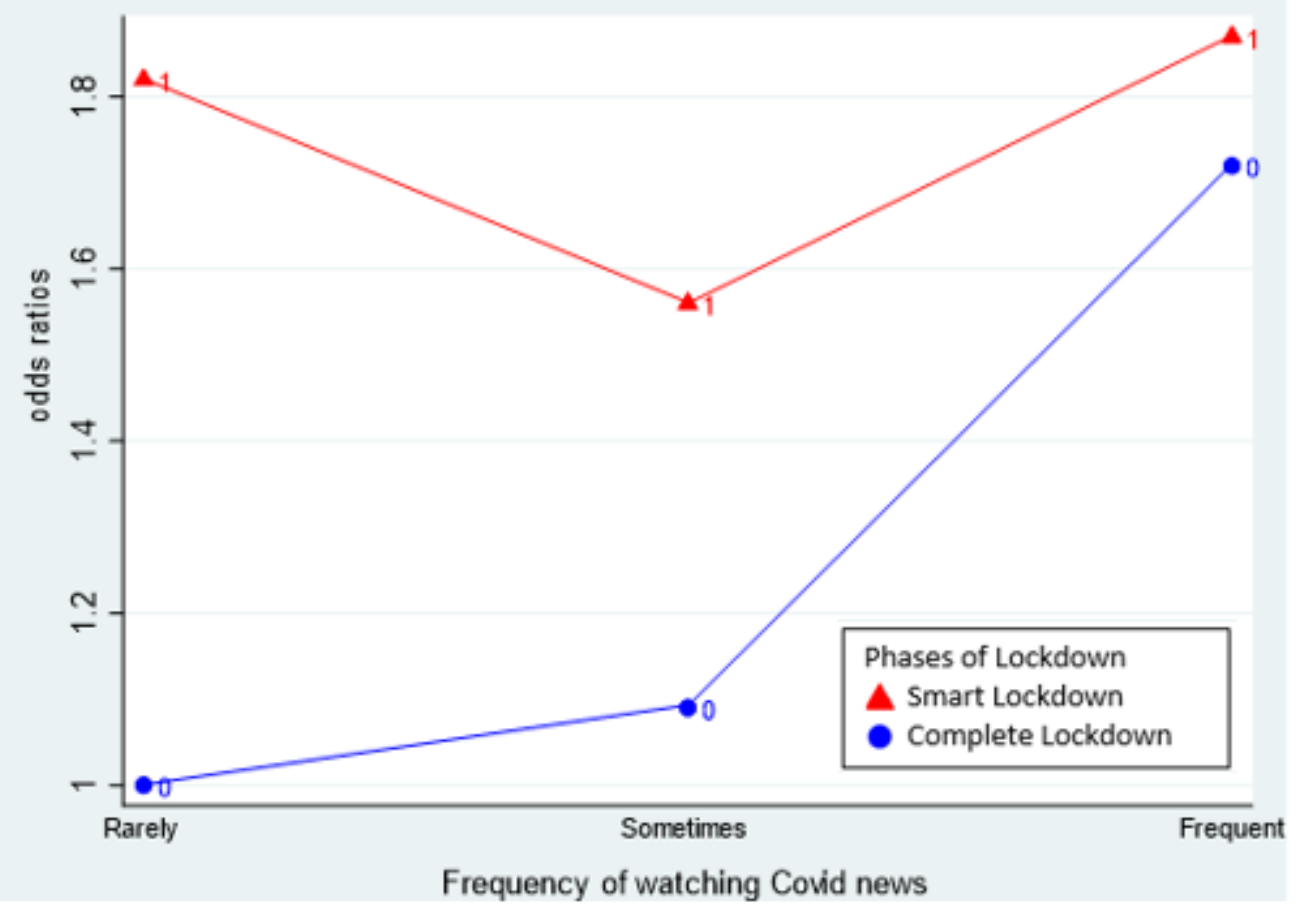

Figure 2

Interaction between phases of lockdown and frequency of watching COVID related news 